Prace Historyczno-Archiwalne t. XXXIII, Rzeszów 2021

ISSN: 1231-3335

\title{
Zenon Andrzejewski
}

ORCID 0000-0002-0066-4726

DOI:10.30657/pha.33.2021.05

(Towarzystwo Przyjaciół Nauk w Przemyślu)

\section{Zarys dziejów \\ przemyskiego Towarzystwa Prawniczego 1872-1939. \\ Przyczynek do historii \\ galicyjskich stowarzyszeń prawniczych}

\begin{abstract}
Streszczenie
Artykuł przedstawia genezę i działalność Towarzystwa Prawniczego w Przemyślu, które powstało w 1872 r. jako czwarte w Galicji (po Krakowie, Lwowie i Kosowie). Stowarzyszenie nie rozwinęło jednak wówczas działalności. Inicjatywa powołania TP odżyła w 1889 r., ale pomimo sprzyjającego klimatu i szerokiego poparcia społecznego (m.in. ze strony prasy lokalnej), Przemyśl musiał poczekać na swoje TP aż do roku 1893. Tym razem działalność organizacji rozwijała się obiecująco (rosła liczba członków, organizowano odczyty, zaczęto kompletować bibliotekę), jednak załamała się nagle w 1902 r., po czym nastąpił 12-letni okres „letargu”. Wznowiona w 1914 r. działalność trwała tylko kilka miesięcy - do wybuchu I wojny światowej. Reaktywacja TP nastąpiła dopiero w 1925 r., dzięki wspólnym staraniom przedstawicieli miejscowej adwokatury i środowiska sądowego. Towarzystwo znów działało prężnie (biblioteka, czytelnia, odczyty z różnych dziedzin prawa, pogadanki, regularne walne zebrania). Władze organizacji starały się również propagować niekonwencjonalne formy szerzenia wiedzy prawniczej, jak np. symulowana rozprawa sądowa czy wycieczka do zakładu poprawczego. W grudniu 1938 r. siedzibę Towarzystwa przeniesiono ze starego gmachu Sądu Okręgowego (Rynek 26) do nowo wybudowanego gmachu sądu przy ul. Konarskiego 6. Z chwilą wybuchu II wojny światowej Towarzystwo Prawnicze w Przemyślu przestało istnieć.
\end{abstract}

\section{Słowa kluczowe:}

Przemyśl, Galicja, Towarzystwo Prawnicze, działalność statutowa, adwokaci, sędziowie. 
$\mathrm{P}$ ierwsze stowarzyszenia prawnicze na ziemiach polskich zaczęły powstawać w II połowie XIX wieku w zaborze austriackim.

Potrzeba zrzeszania się prawników galicyjskich wiązała się ze stałym wzrostem ich liczby, odczuwaną koniecznością integracji różnych gremiów prawniczych, a przede wszystkim stanowiła wyraz naukowych i zawodowych aspiracji środowiska.

W roku 1867 powołano do życia Towarzystwo Prawnicze w Krakowie, mające na celu rozwijanie, zarówno $\mathrm{w}$ teorii, jak i w praktyce, prawoznawstwa oraz nauk ekonomiczno-społecznych ${ }^{1}$.

W marcu 1868 r. powstało Towarzystwo Prawnicze we Lwowie, a jego podstawowym zadaniem programowym było „uprawianie w duchu narodowym polskich nauk prawnych i społecznych, w teorii i praktyce"2.

W roku 1872 założono Towarzystwo Prawnicze w Kosowie³, które za główny cel przyjęło upowszechnianie wśród swoich członków szeroko rozumianej wiedzy prawniczej ${ }^{4}$.

Jako czwarte w kolejności zawiązało się w Galicji Towarzystwo Prawnicze w Przemyślu ${ }^{5}$. Statut Towarzystwa został zatwierdzony reskryptem c.k. Namiestnictwa we Lwowie z 5 października 1872 r., L. 43773, a zebranie konstytuujące odbyło się 24 listopada tegoż roku. W skład Wydziału (Zarządu) weszli: adwokat dr Aleksander Dworski jako prezes, prokurator dr Józef Prachtel - zastępca prezesa oraz członkowie: adwokaci dr Erazm Łobaczewski i dr Walery Waygart, notariusz Kazimierz Frankowski, dr Dębicki i dr Krotochwil ${ }^{6}$. Niestety, nowo powstałe stowarzy-

1 A. Pollok, Powstanie i rozwój Towarzystwa Ekonomicznego w Krakowie, [w:] Polskie Towarzystwo Ekonomiczne, Zeszyty Naukowe Polskiego Towarzystwa Ekonomicznego, Kraków 2006, nr 4, s. 1-2. Podobną datę założenia krakowskiego Towarzystwa podaje B. Krajewska-Tartakowska - zob. eadem, Towarzystwo Prawnicze w Krakowie, [w:] Słownik Polskich Towarzystw Naukowych, t. II, cz. 3, Biblioteka PAN w Warszawie, Warszawa 2001, s. 110. Statut Towarzystwa został zarejestrowany reskryptem c.k. Namiestnictwa we Lwowie z dnia 29 stycznia $1868 \mathrm{r}$.

2 Towarzystwo Prawnicze we Lwowie, Szematyzm Królestwa Galicji i Lodomerii z Wielkim Księstwem Krakowskim na rok 1895, Lwów 1895, s. 669. M. Kamler podaje, że Towarzystwo Prawnicze we Lwowie zostało założone jeszcze wcześniej, bo w roku 1865, co wydaje się mało prawdopodobne - zob. idem, Leksykon Historii Polski, Wiedza Powszechna, Warszawa 1995, s. 1094.

3 B. Krajewska-Tartakowska, Kosowskie Towarzystwo Prawnicze, [w:] Słownik Polskich..., s. 50. Statut Towarzystwa został zatwierdzony przez c.k. Namiestnictwo we Lwowie w lutym 1872 r. Natomiast wg T.J. Kotlińskiego, Towarzystwo Prawnicze w Kosowie powstało w roku 1871 - zob. idem, Towarzystwa Prawnicze w Galicji Wschodniej w II połowie XIX oraz I połowie XX wieku, „Rocznik Przemyski” 2008, t. XLIV, Historia, z. 4, s. 141.

4 Szerzej na ten temat B. Krajewska-Tartakowska, Kosowskie Towarzystwo..., s. 50-51.

5 Towarzystwo Prawnicze w Przemyślu, „Prawnik” z 11 grudnia 1872 r., nr 50, s. 200. Do tej pory, z powodu zaginięcia w czasie II wojny światowej prymarnych dokumentów stowarzyszenia (archiwaliów), których nie odnaleziono do dnia dzisiejszego pomimo wieloletnich poszukiwań, nie ukazała się żadna praca monograficzna ani artykuł poświęcony historii przemyskiego Towarzystwa. Stąd niniejszy artykuł jest pierwszą próbą odtworzenia historii stowarzyszenia, w oparciu o źródła wtórne, tj. lokalną prasę przemyską oraz branżową, i dlatego zasygnalizowano $\mathrm{w}$ tytule, że jest to zarys.

6 „Prawnik” z 11 grudnia 1872 r., nr 50, s. 200. 
szenie nie rozwinęło działalności statutowej ${ }^{7}$ i wkrótce zakończyło swój byt prawny z powodu bezczynności ${ }^{8}$.

We wrześniu 1887 r., na odbywającym się w Krakowie I Zjeździe Prawników i Ekonomistów Polskich, na wniosek prof. dr. Franciszka Ksawerego Kasparka podjęto uchwałę „uznającą potrzebę tworzenia Towarzystw Prawniczych w każdym miejscu siedziby sądu" ". Jako wzór podawano działające od 15 lat z dużym powodzeniem Towarzystwo Prawnicze w Kosowie, chociaż w miejscowości tej liczba prawników była niewielka.

W Przemyślu sprawa powołania Towarzystwa Prawniczego, zgodnie z postulatami I Zjazdu Prawników i Ekonomistów, odżyła w lutym 1889 r. Wtedy to, z inicjatywy podprokuratora dr. Alfonsa Bieńczewskiego, radca dworu Pressen zwołał zebranie urzędników miejscowego Sądu Obwodowego o twórczych umysłach („konceptowych"), w celu zastanowienia się nad celowością i możliwością realizacji wspomnianej wyżej uchwały Zjazdu, a w szczególności zawiązania w Przemyślu takiego Towarzystwa ${ }^{10}$. Na zebraniu tym nie podjęto jednak ostatecznej decyzji co do meritum sprawy. Wybrano tylko komisję, która miała dogłębnie przemyśleć potrzebę powołania Towarzystwa Prawniczego, opracować konkretne wnioski i przedstawić je za miesiąc.

Dążenia do utworzenia w Przemyślu Towarzystwa Prawniczego poparła „Gazeta Przemyska”, która w artykule odredakcyjnym pisała: „(...) Inicjatywie wyszłej z najpoważniejszego grona prawników tutejszych przyklasnąć tylko możemy (...). Mniemamy, że wszelkie zastanawianie się nad potrzebą i możnością zawiązania takiego Towarzystwa jest zbyteczne i raczej komisja wprost do czynności zawiązania, a więc do ułożenia statutu i zbierania członków dla przyszłego Towarzystwa przystąpić powinna"11.

Zdaniem redakcji „Gazety Przemyskiej”, w Towarzystwie Prawniczym młodzi prawnicy mieliby możliwość uzupełniania swojej teoretycznej wiedzy, wyniesionej z uniwersytetu, wiadomościami praktycznymi poprzez wymianę doświadczeń z kolegami praktykami. Stowarzyszenie się w jednym kole pozwoliłoby „wzajemnie udzielać i rozbierać spostrzeżenia poczynione w zastosowaniu praw w rozmaitych gałęziach służby prawniczej, omawiać nowe prawa, odnaleźć się i zbliżyć prawnikom różnych specjalności zawodowych"12. Ponadto, powstanie Towarzystwa Prawniczego stworzyłoby szansę zorganizowania, przy niewielkich składkach członków, biblioteki prawno-ekonomicznej. „Materiału na członków Towarzystwa Prawniczego jest w Przemyślu pod dostatkiem. W sądzie, starostwie, powiatowej dyrekcji skarbu,

7 Nie był to przypadek odosobniony. Podobnie, nie rozwinęło działalności, w ciągu pierwszych dwudziestu lat od założenia, Towarzystwo Prawnicze w Krakowie. Podaję za: B. Krajewska-Tartakowska, Towarzystwo Prawnicze w Krakowie..., s. 110.

8 Po roku 1872 nie ma jakiegokolwiek źródłowego potwierdzenia oznak żywotności przemyskiego Towarzystwa. Jak się wydaje, spowodowane to było brakiem zainteresowania środowiska sądowniczego pracami stowarzyszenia i trudnościami z naborem członków. „Gazeta Przemyska” z 24 lutego 1889 r., nr 8, s. 1, pisze wprost, że zapaść Towarzystwa Prawniczego w Przemyślu była wynikiem „apatii” prawników sądowych.

9 „Przegląd Prawa i Administracji”, r. XIX, Lwów 1894, s. 895.

10 „Gazeta Przemyska” 1889, nr 8, s. 1.

11 Ibidem.

12 Ibidem. 
w adwokaturze naliczylibyśmy przeszło 90 adeptów prawa. Aby jednak Towarzystwo się dobrze rozwijało, nie należy mu nadawać cechy zbyt teoretycznej, praktycy bowiem, szczególniej starsi, nie lubią zaciekać się w teoretyczne wywody, natomiast rozbieranie praktycznych wypadków, orzeczeń Najwyższego Sądu i Trybunału Administracyjnego, zastanawianie się nad zastosowaniem nowych ustaw pożądanym i interesującym będzie dla wszystkich” - pisała wspomniana „Gazeta Przemyska”13. Jednak, pomimo sprzyjającego klimatu i poparcia społecznego, kolejna próba utworzenia w Przemyślu Towarzystwa Prawniczego zakończyła się niepowodzeniem.

Na powstanie Towarzystwa miasto musiało czekać jeszcze niemal pięć lat, a nastąpiło to dopiero 10 czerwca 1893 roku $^{14}$. Tego dnia, dzięki staraniom prezydenta Sądu Obwodowego w Przemyślu dr. Jana Dylewskiego oraz adwokata dr. Bernarda Gansa odbyło się historyczne I Walne Zgromadzenie Towarzystwa, w którym wzięło udział 52 członków oraz prezes przemyskiej Izby Adwokatów, dr Wacław Skórski. Założycielskiemu zebraniu przewodniczył prezydent miasta, adwokat dr Aleksander Dworski. W wyborach do władz Towarzystwa funkcję prezesa powierzono jednogłośnie dr. Janowi Dylewskiemu, zaś w skład Wydziału jako członkowie weszli: dr Alfons Bieńczewski - c.k. podprokurator, Ksawery Spławski - c.k. radca sądowy, dr Wilhelm Rosenbach - adwokat krajowy, dr Leonard Tarnawski - adwokat krajowy, Julian Nestorowicz - c.k. radca skarbowy i Stanisław Linde - c.k. komisarz namiestnikowski ${ }^{15}$. Zastępcami członków Wydziału wybrani zostali: Tadeusz Malina - c.k. adiunkt sądowy, Hugon Królikowski - c.k. adiunkt sądowy, Antoni Sołtysik - c.k. nadkomisarz skarbowy, Bazyli Malarkiewicz - c.k. auskultant sądowy, dr Bernard Gans - adwokat krajowy i dr Teofil Kormosz - adwokat krajowy ${ }^{16}$. Na swoim pierwszym posiedzeniu Wydział ukonstytuował się w sposób następujący: zastępcą prezesa Towarzystwa wybrano dr. Leonarda Tarnawskiego, sekretarzem i bibliotekarzem dr. Alfonsa Bieńczewskiego, kasjerem dr. Wilhelma Rosenbacha ${ }^{17}$. Na gospodarza powołano Hugona Królikowskiego, na zastępcę sekretarza dr. Bernarda Gansa, na zastępcę bibliotekarza Bazylego Malarkiewicza, na zastępcę kasjera dr. Teofila Kormosza ${ }^{18}$.

Na drugim posiedzeniu Wydziału, 7 lipca 1893 r., uchwalono regulamin Towarzystwa, identyczny z regulaminem Towarzystwa Prawniczego we Lwowie ${ }^{19}$. Walne

13 Ibidem.

14 Mora, Towarzystwo Prawnicze w Przemyślu, „Przegląd Prawa i Administracji”, r. XVIII, cz. I, Lwów 1893, s. 640.

15 Ibidem. Współudział dr. B. Gansa przy założeniu Towarzystwa podaje „Głos Prawa” z 1935 r., nr 3-4, s. 256.

16 Mora, op. cit.

17 Ibidem.

18 Ibidem.

19 Ibidem. Lwowskie Towarzystwo Prawnicze miało następujące zadania programowe: „(...) uprawianie $\mathrm{w}$ duchu narodowym polskich nauk prawnych i społecznych, $\mathrm{w}$ teorii i praktyce, przez wykłady, wspólne narady i rozbiory, sprawozdania, wydawanie opinii, opracowywanie wniosków w przedmiotach zakresem Towarzystwa objętych, urządzanie wieców i przygotowywanie materiałów do obrad wiecowych w myśl osobnego regulaminu wiecowego z dnia 16 września 1894 r., wydawanie dzieł naukowych, podręczników praktycznych i czasopism, popieranie prac literackich i premiowanie dzieł lub rozpraw $w$ dziedzinie umiejętności prawa dla nauk społecznych, utrzymywanie organu Towarzystwa („Przegląd Prawa i Administra- 
Zgromadzenie wszystkich członków Towarzystwa miało kompetencje wyborcze, uchwałodawcze i kontrolne, a Wydział, któremu przewodniczył prezes, był organem wykonawczym. Prezes reprezentował też Towarzystwo Prawnicze na zewnątrz.

Powstałe po ponad 20 latach niebytu, przemyskie Towarzystwo Prawnicze nie było reaktywacją Towarzystwa z 1872 r., o którym w roku 1893 nikt już nie pamiętał. Nie wspominał o nim nawet pierwszy prezes Towarzystwa, dr Aleksander Dworski, bowiem stowarzyszenie, którym miał kierować, de facto nie podjęło żadnej działalności, stąd trudno dopatrywać się ciągłości prawnej między obydwiema organizacjami. Towarzystwo Prawnicze powstałe w 1893 r. było całkowicie nowym tworem organizacyjnym i nie uznawało się za spadkobiercę, względnie kontynuatora, swego poprzednika z 1872 roku.

W ciągu pierwszego roku istnienia liczba członków stowarzyszenia wzrosła do 80 osób, rozpoczęto kompletowanie biblioteki z zakresu nauk prawno-społecznych, a adwokaci Leonard Tarnawski, Jan Niemczyński, Wilhelm Rosenbach i nadkomisarz skarbowy Antoni Sołtysik zainaugurowali działalność odczytową Towarzystwa, dzieląc się ze słuchaczami doświadczeniami ze swej bogatej praktyki zawodowej ${ }^{20}$.

16 września 1894 r. odbył się we Lwowie, w sali obrad lwowskiej Izby Adwokatów, I Zjazd Delegatów Krajowych Towarzystw Prawniczych. Przemyskie Towarzystwo reprezentowali: prezes Towarzystwa i prezydent Sądu Obwodowego dr Jan Dylewski, sędzia dr Włodzimierz Haszczyc, adwokaci dr Bernard Gans i dr Erazm Łobaczewski oraz Michał Nieświatowski. Jan Dylewski i Erazm Łobaczewski zostali wybrani na zastępców przewodniczącego Zjazdu, natomiast Michał Nieświatowski został jednym z dwóch sekretarzy ${ }^{21}$.

„Kuryer Przemyski” z 23 grudnia 1894 r. donosił, że „(...) Towarzystwo Prawnicze daje oznaki swej żywotności. W piątek, 21 grudnia 1894 r., odbył się już trzeci wykład adw[okata] dr. Włodzimierza Błażowskiego o projekcie nowej procedury cywilnej, a licznie zebrani członkowie Towarzystwa, po skończonym wykładzie prowadzili jeszcze długo ożywioną dyskusję"22. Ten sam prelegent 12 marca 1895 r. wygłosił odczyt pt. „O normie jurysdykcyjnej wedle nowego projektu procedury cywilnej”23.

W dniach 23 i 24 marca 1895 r. gościem przemyskiego Towarzystwa Prawniczego był zaproszony przez Wydział Towarzystwa profesor Uniwersytetu Lwowskiego, dr August Balasits, który wygłosił przed licznym audytorium w sali rozpraw głównych Sądu Obwodowego dwa wykłady o projekcie nowej procedury cywilnej, a mianowicie „o kierownictwie procesu i protokołowaniu”. Na zakończenie krótkiego pobytu dostojnego prelegenta w Przemyślu władze Towarzystwa wydały w hotelu „Victoria” na jego cześć „ucztę, której przebieg był ożywiony i nacechowany koleżeńską serdecznością"24.

20 kwietnia 1895 r., w sali rozpraw Sądu Obwodowego, odbyło się Walne Zebranie Towarzystwa, w którym uczestniczyło 32 członków. Wybrano na rok 1895

cji"), staranie o jednolitą terminologię w nauce, praktyce, ćwiczenia w wymowie, urządzanie czytelni oraz utrzymywanie biblioteki dzieł i czasopism fachowych, popieranie tworzenia i rozwoju Towarzystw Prawniczych w kraju i utrzymywanie z nimi łączności, zebrania towarzyskie (...)". Szematyzm Królestwa... na rok 1895, Lwów 1895, ss. 669-670.

20 „Przegląd Prawa i Administracji”, r. XIX, Lwów 1894, s. 402.

21 Ibidem, s. 894-895; „Prawnik” z 28 września 1894 r., nr 13, s. 195.

22 „Kuryer Przemyski” 1894, nr 7, s. 3.

23 „Kuryer Przemyski” 1895, nr 28, s. 3 (zapowiedź ukazała się z wyprzedzeniem).

24 „Przegląd Prawa i Administracji”, r. XX, Lwów 1895, s. 416; „Kuryer Przemyski” 1895, nr 33, s. 3. 
nowy Wydział. Funkcję prezesa powierzono ponownie dr. Janowi Dylewskiemu, zaś członkami wybrano: dr. Alfonsa Bieńczewskiego, Hugona Królikowskiego, dr. Wilhelma Rosenbacha, Ksawerego Spławskiego, dr. Leonarda Tarnawskiego i Włodzimierza Wilkego. Ich zastępcami zostali: dr Włodzimierz Błażowski, dr Bernard Gans, dr Teofil Kormosz, Tadeusz Malina, Antoni Sołtysik i dr Eugeniusz Zawisłocki ${ }^{25}$.

Na 25 listopada 1895 r. „Kuryer Przemyski” zapowiadał zebranie towarzyskie członków Towarzystwa, na którym „adwokat dr Rosenbach będzie miał rzecz o nowym procesie cywilnym"26.

W pierwszej połowie października 1896 r. rozpoczął się w Towarzystwie Prawniczym cykl wykładów na temat nowej normy jurysdykcyjnej, nowej procedury cywilnej, nowej ustawy egzekucyjnej, odnośnych ustaw wprowadzających oraz projektowanej ustawy o organizacji sądów. Wykłady trwały do końca kwietnia 1897 r., a prelegentami byli: radcowie sądowi W. Wilke, Mikłaszewski, Fido, Seidler-Wiślański, dr A. Bieńczewski, Szwedzicki, Folusiewicz, sekretarze rady dr E. Zawisłocki i dr H. Królikowski, adiunkt sądowy T. Malina oraz adwokaci: dr Gans, dr Rosenbach, dr Tarnawski i dr Peiper ${ }^{27}$. Działalność odczytową przemyskiego Towarzystwa Prawniczego w roku 1896 tak skomentował „Kuryer Przemyski”: „Wykłady z dziedziny nowego procesu cywilnego, urządzane staraniem Towarzystwa każdej soboty, cieszą się nader licznym udziałem słuchaczy ze sfer zainteresowanych. Nie tylko miasto Przemyśl, ale i okolica wysyła adeptów Temidy do sali rozpraw Sądu Obwodowego, gdzie odbywają się wykłady, tak że sala wcale obszerna bywa chwilami za ciasną"28.

Rozwijająca się tak obiecująco działalność Towarzystwa załamała się nagle w roku 1902. 12 kwietnia odbyło się ostatnie - jak się okazało - posiedzenie ${ }^{29}$, po którym w życiu stowarzyszenia nastąpił długi okres stagnacji. Na dwanaście lat zniknęły z przemyskiej prasy i lwowskiego „Przeglądu Prawa i Administracji” wszelkie informacje o istnieniu i poczynaniach Towarzystwa. Dziennikarz „Ziemi Przemyskiej” nazwał ten okres czasem „letargu"30.

Działalność Towarzystwa została wznowiona dopiero 25 marca 1914 r., kiedy to, dzięki zabiegom prezesa przemyskiego Sądu Obwodowego, dr. Antoniego Wileckiego, odbyło się Walne Zebranie, na którym wybrany jeszcze w roku 1902 Wydział, reprezentowany przez adw. dr. L. Tarnawskiego i skarbnika adw. dr. W. Rosenbacha, złożył sprawozdanie ze stanu stowarzyszenia i jego funduszów, po czym wybrano nowy zarząd Towarzystwa, z prezesem Antonim Wileckim na czele ${ }^{31}$. W skład zarządu, jako członkowie, weszli: adw. dr Leonard Tarnawski, wiceprezes Sądu Obwodowego dr Stanisław Drozdowski, radca sądowy Władysław Grzędzielski, adw. dr Joachim Goldfarb, sędzia okręgowy Stanisław Lesser i adw. dr Bernard Gans. Ich zastępcami zostali: nadradcy Walerian Hoszek i Włodzimierz Lityński oraz radcy Roman Czajkowski, Stanisław Olszewski i Jacek Baj ${ }^{32}$. Do komisji kontrolującej wybrano radców

25 „Kuryer Przemyski” 1895, nr 41, s. 3.

26 Ibidem, nr 101, s. 2.

27 „Kuryer Przemyski” 1896, nr 76, s. 2.

28 Ibidem, nr 87, s. 2.

29 „Echo Przemyskie” 1902, nr 29, s. 3.

30 „Ziemia Przemyska” 1914, nr 14, s. 5. Autorowi artykułu nie udało się zbadać przyczyn tego zastoju, gdyż nie zachowała się żadna dokumentacja Towarzystwa.

31 Ibidem.

32 Ibidem. 
Kazimierza Brzezińskiego i dr. Józefa Mierzeńskiego oraz rejenta Jana Kantego Krupińskiego $^{33}$. Niestety, już kilka miesięcy później, wraz z wybuchem I wojny światowej, działalność przemyskiego Towarzystwa Prawniczego całkowicie zamarła.

Stowarzyszenie zostało przywrócone do życia dopiero w 1925 roku. W literaturze występują rozbieżności co do udziału jego reaktywatorów. Według „Ziemi Przemyskiej” z 1925 r., inicjatywa w sprawie restytucji wyszła od prezesa Sądu Okręgowego, dr. Antoniego Wileckiego ${ }^{34}$. „Głos Prawa” z 1927 r. podaje, że stało się to „z inicjatywy adw. dr. Leona Peipera ${ }^{35}$, popartej z nadzwyczajnym zapałem przez prezesa Sądu Okręgowego w Przemyślu p. Wileckiego”36. Natomiast „Głos Prawa” z 1935 r. reaktywowanie Towarzystwa Prawniczego w Przemyślu przypisuje prezesowi Sądu Okręgowego dr. Antoniemu Wileckiemu oraz prezesowi przemyskiej Izby Adwokatów dr. Leonardowi Tarnawskiemu i adwokatowi dr. Leonowi Peiperowi ${ }^{37}$.

W tej sytuacji zasadny będzie pogląd, że odrodzenie Towarzystwa Prawniczego w Przemyślu po I wojnie światowej nastąpiło dzięki wspólnym staraniom przedstawicieli miejscowej adwokatury i środowiska sądowniczego.

Na dzień 2 czerwca 1925 r. zostało zwołane Walne Zgromadzenie przedwojennych członków Towarzystwa oraz osób ze sfer prawniczych, deklarujących wolę przystąpienia do reaktywowanego stowarzyszenia ${ }^{38}$.

W niedzielę, 7 czerwca 1925 r., w sali rozpraw karnych Sądu Okręgowego w Przemyślu odbyło się zebranie konstytuujące Towarzystwa. Po dopełnieniu formalności wybrano Wydział Towarzystwa, do którego weszli: prezes Sądu Okręgowego dr Antoni Wilecki jako przewodniczący, adw. dr Leon Peiper - zastępca przewodniczącego ${ }^{39}$, prokurator dr Jan Prochazka - sekretarz, radca Izaak Gans skarbnik oraz adwokaci dr Adam Kropiński ${ }^{40}$ i dr Wilhelm Redlich jako bibliotekarze. Członkami Wydziału zostali: adwokaci dr Józef Dobrzański, dr Józef Rawicz, dr Maurycy Richter ${ }^{41}$, sędziowie Sądu Okręgowego dr Władysław Markiewicz, dr Fryderyk Rosenfeld, dr Tadeusz Dyduszyński oraz starosta Henryk Kassala ${ }^{42}$. Do komisji rewizyjnej powołano: radcę skarbowego Medarda Czaudernę, sędziego okręgowego Jana Porembalskiego i adw. dr. Józefa Palcha ${ }^{43}$.

12 czerwca 1925 r. odbyło się pierwsze posiedzenie Wydziału, na którym uchwalono, aby uruchomić w najbliższej przyszłości bibliotekę Towarzystwa, zakupić do

33 Ibidem.

34 „Ziemia Przemyska” 1925, nr 23, s. 3.

35 Zob. więcej: Z. Andrzejewski, A. Redzik, Leon Peiper (1865-1942) - zapomniany wybitny uczony i adwokat, „Palestra” 1-2/2008, s. 177-190.

36 „Głos Prawa” 1927, nr 4, s. 152. Tam błędna data zawiązania Towarzystwa (1897).

37 "Głos Prawa” 1935, nr 3-4, s. 256.

38 „Ziemia Przemyska” 1925, nr 23, s. 3.

39 Z czasem w praktyce wykształcił się zwyczaj, że prezesem przemyskiego Towarzystwa Prawniczego był każdorazowy prezes Sądu Okręgowego, zaś wiceprezesem członek miejscowej Izby Adwokackiej.

40 Zob. Z. Andrzejewski, Adwokat Adam Kropiński (1887-1944) - życie, praca zawodowa oraz działalność społeczna, polityczna i kulturalna, „Palestra” 11-12/2013, s. 276-284.

41 Zob. Z. Andrzejewski, Adwokat dr Maurycy Richter (1887-1954), „Przemyskie Zapiski Historyczne", r. XVIII: 2010-2011, Przemyśl 2013, s. 191-198.

42 „Ziemia Przemyska” 1925, nr 25, s. 4.

43 Ibidem. 
niej aktualną literaturę jurystyczną oraz zaprenumerować wszystkie wychodzące w Polsce czasopisma prawnicze ${ }^{44}$. Na lokal zebrań towarzyskich prezes Wilecki wyznaczył główną salę rozpraw karnych, na czytelnię zaś i bibliotekę - salę narad 14a, dokąd też przeniesiono szafy z książkami ${ }^{45}$. Następnie rozdzielono referaty (działy tematyczne, odpowiedniki sekcji). Referaty ustaw cywilnych i administracyjnych objęli adwokaci Józef Rawicz i Maurycy Richter, referaty ustaw karnych i orzecznictwa karnego - prokurator Jan Prochazka, referat orzecznictwa cywilnego - sędziowie Władysław Markiewicz, Fryderyk Rosenfeld i Tadeusz Dyduszyński, a referat projektów ustaw przypadł adwokatowi L. Peiperowi ${ }^{46}$, który też odpowiadał za organizowanie cotygodniowych wykładów. Biblioteka i czytelnia Towarzystwa zostały uruchomione w ostatnim tygodniu stycznia 1926 roku. „Ziemia Przemyska” informowała: „(...) Czytelnia i biblioteka otwarte będą codziennie w godzinach urzędowych od 9 do 15. Ponadto dla wygody członków lokal Towarzystwa będzie otwarty i w godzinach popołudniowych za zgłoszeniem się u woźnego Winiarskiego, kursora Towarzystwa. Lokal Towarzystwa, stosownie do swego przeznaczenia, odświeżony, odmalowany i urządzony, będzie stale opalony, a w godzinach popołudniowych elektrycznie oświetlony. Dla wygody pp. adwokatów będzie prowadzona w lokalu Towarzystwa drobna sprzedaż stempli, podobnie jak w latach przedwojennych oraz drobna sprzedaż wyrobów tytoniowych" ${ }^{\prime 7}$.

Przemyskie Towarzystwo Prawnicze pracowało w oparciu o uchwalony statut $^{48}$. Raz do roku prezes Towarzystwa zwoływał zwyczajne Walne Zgromadzenie wszystkich członków, na którym omawiano sprawy bieżące, składano sprawozdania z działalności odczytowej, pracy biblioteki, stanu finansów Towarzystwa i wybierano władze stowarzyszenia ${ }^{49}$. W razie potrzeby zwoływane były zgromadzenia nadzwyczajne. Jak podaje „Ziemia Przemyska”, na Walnym Zgromadzeniu, które odbyło się w niedzielę 5 października 1930 r. w sali rozpraw karnych Sądu Okręgowego, sprawozdanie z działalności Wydziału złożył zastępca prezesa, adw. dr Leon Peiper, a sprawozdanie kasowe - skarbnik adw. dr Leon Probstein. Przychody Towarzystwa wynosiły 2168,24 zł, a wydatki 2150,07 zł. Zgromdzenie wybrało nowy Wydział przewodniczącym został prezes Sądu Okręgowego, sędzia Włodzimierz Hanińczak, a jego zastępcami - adw. dr Józef Axer ${ }^{50}$ i sędzia okręgowy Władysław Baldini. Ponadto w skład Wydziału jako członkowie weszli: adw. dr Józef Dobrzański, sędzia powiatowy Frenkel, adw. dr Adam Kropiński, sędzia Sądu Okręgowego dr Kwasik, adw. dr Leon Peiper, sędzia Sądu Okręgowego Włodzimierz Podłuski, adw. dr Leon Probstein, prokurator dr Jan Prochazka, adw. dr Józef Rawicz i sędzia Sądu Okręgowego Szymański ${ }^{51}$.

Walnemu Zebraniu Towarzystwa, zwołanemu w niedzielę 6 października 1935 r. w dużej sali Sądu Okręgowego, przewodniczył prezes delegacji adwokatów,

44 Ibidem.

45 Ibidem.

46 Ibidem.

47 „Ziemia Przemyska” 1926, nr 6, s. 3.

48 Niestety, tekst tego dokumentu nie zachował się.

49 Zwyczajne walne zgromadzenia były zwoływane na podstawie $\S 9$ statutu Towarzystwa. „Tygodnik Przemyski” 1938, nr 40, s. 4; „Nowy Głos Przemyski” 1938, nr 40, s. 3.

50 Zob. Z. Andrzejewski, Adwokat dr Józef Axer (1882-1957), „Palestra” 11-12/2004, s. 161-164.

51 „Ziemia Przemyska” 1930, nr 59, s. 3. 
dr Józef Scheinbach, a funkcję sekretarza pełnił sędzia Sądu Okręgowego dr Marcin Rzeszutko. Sprawozdanie z działalności zarządu (Wydziału) za rok 1934, które wykazało szczególnie ożywioną działalność odczytową Towarzystwa, złożył prezes Prochazka, za co zgromadzeni wyrazili organizatorom specjalne podziękowania. Po przyjęciu sprawozdania kasowego adwokata dr. Józefa Rawicza, dokonano wyboru władz Towarzystwa. Przewodniczącym zarządu został ponownie prezes Sądu Okręgowego dr Jan Prochazka, a wiceprzewodniczącym - adw. dr Leon Peiper. Ponadto w skład zarządu weszło 10 członków ${ }^{52}$.

Kolejne Walne Zgromadzenie przemyskiego Towarzystwa Prawniczego odbyło się 16 października 1936 r. w sali przysięgłych Sądu Okręgowego. Zagaił je dotychczasowy przewodniczący, dr Jan Prochazka, na którego wniosek przewodnictwo zebrania powierzono przewodniczącemu delegacji Rady Adwokackiej, dr. J. Scheinbachowi. Sekretarzował sędzia Sądu Okręgowego dr Emil Gottas. Sprawozdanie z pracy zarządu zdał prezes Prochazka, a sprawozdanie kasowe przedłożył dr Józef Rawicz. Po krótkiej dyskusji jednomyślnie wyrażono podziękowanie ustępującemu zarządowi za intensywną pracę, szczególnie za uporządkowanie biblioteki, a następnie dokonano wyboru władz Towarzystwa w dotychczasowym składzie. Po zebraniu dr Rawicz wygłosił interesujący wykład o praktyce i orzecznictwie według nowej procedury cywilnej ${ }^{53}$.

W roku 1937 siedziba Towarzystwa mieściła się w Rynku pod numerem $24^{54}$.

Towarzystwo prowadziło dynamiczną działalność odczytową, która stała się podstawową formą jego pracy. Wykłady i odczyty odbywały się w budynku Sądu Okręgowego (Rynek 26), w głównej sali rozpraw karnych nr 14 na II piętrze ${ }^{55}$, każdego piątku o godz. 18.00. Dotyczyły one zagadnień z różnych dziedzin prawa, nowych uregulowań w wydawanych ustawach polskich (wekslowej, należytościowej, karnej, skarbowej, o reformie rolnej), projektów ustawy o postępowaniu karnym oraz innej aktualnej problematyki prawniczej ${ }^{56}$. 0 tematyce odczytów decydowali prelegenci lub swoje propozycje zgłaszali członkowie Towarzystwa. Oprócz tego odbywały się dyskusje (pogadanki) na temat bieżących kwestii prawnych, z wyjątkiem sporów zawisłych w sądach przemyskich - powiatowym i okręgowym ${ }^{57}$.

Referaty, wykłady i odczyty wygłaszane na zebraniach Towarzystwa Prawniczego miały de facto charakter szkoleń zawodowych, opartych na wiedzy teoretycznej i doświadczeniu praktycznym prelegentów. Były zawsze bardzo starannie przygotowane, stały na wysokim poziomie i cieszyły się wysoką frekwencją ${ }^{58}$. Uczestniczyli w nich nie tylko członkowie Towarzystwa, ale także sędziowie, prokuratorzy, adwokaci, aplikanci sędziowscy i prawnicy innych profesji z okolicznych miejscowości. Ponadto, zgodnie z zaleceniem Wydziału przemyskiej Izby Adwokatów, na wykłady Towarzystwa Prawniczego mieli również uczęszczać aplikanci adwokaccy ${ }^{59}$.

52 „Nowy Głos Przemyski” 1935, nr 41, s. 4.

53 „Nowy Głos Przemyski” 1936, nr 43, s. 4.

54 Informator Rzeszowski Jarosławsko-Przemyski, Rocznik 1937/38, wyd. J. Brunelik, Lwów-Kraków 1937, s. 74.

55 Patrz przypis 53.

56 „Głos Prawa” 1927, nr 4, s. 152; zob. także przypis 53.

57 „Tygodnik Przemyski 1928, nr 42, s. 2; „Ziemia Przemyska” 1928, nr 43, s. 3.

58 Patrz przypis 53.

59 Sprawozdanie Wydziału Izby Adwokatów w Przemyślu za rok 1931, Przemyśl 1932, s. 12. 
Do najaktywniejszych prelegentów Towarzystwa należeli adwokaci: $\mathrm{dr} d r$ Leon Peiper, Józef Rawicz, Adam Kropiński, Emil Morgenstern, Adolf Frim, Oswald Bethauer, Ozjasz Rast i Ludwik Grossfeld ${ }^{60}$ oraz sędziowie Sądu Okręgowego: dr dr Adolf Hornik, Michał Dietz, Antoni Czerny, Emil Eisner, Włodzimierz Podłuski i Włodzimierz Haszczyc ${ }^{61}$. Do działalności prelekcyjnej włączali się też sędziowie przemyskiego Sądu Grodzkiego, rzadziej prokuratorzy, radcowie sądowi, sporadycznie notariusze, sędziowie wojskowi, a nawet aplikanci ${ }^{62}$.

Oprócz odczytów, władze Towarzystwa starały się propagować inne atrakcyjne formy pracy i szerzenia wiedzy prawniczej. Przykładowo, 14 czerwca 1929 r. w przemyskim Sądzie Okręgowym odbyła się symulowana rozprawa główna według przepisów nowej procedury karnej, mającej wejść w życie 1 lipca 1929 r. Rozprawie przewodniczył sędzia Sądu Okręgowego dr Włodzimierz Podłuski, a członkami zespołu orzekającego byli: w pierwszej części sędziowie Sądu Okręgowego Wacław Romanowski i Jan Rozdół, a w drugiej - Zygmunt Krzewiński i Emil Eisner. Protokołowała mgr praw Gabriela Rastówna. W prokuratora wcielił się sędzia okręgowy Jurkiewicz, a obrońcami byli adwokaci: dr dr Ferdynand Brandstätter, Adolf Frim, Abraham Gottdank i Dawid Landau. W relacji z tego pozorowanego procesu sprawozdawca sądowy „Ziemi Przemyskiej” napisał: „(...) Wszyscy dobrze wypełnili swoje zadania, poruszając rozmaite kwestie unormowane inaczej, niż w dotychczasowej ustawie i nadając rozprawie pełne pozory rzeczywistości. Udolnie odtworzyli role oskarżonych sędzia Cionka, dr Schorr, dr Morgenrot i dr Tannenbaum. Wesoło wypadł zaimprowizowany występ sędziego okręgowego Metzgera, który, wystąpiwszy z grona publiczności, zaprzeczył sądowi prawa sądzenia wedle nowej ustawy, która jeszcze nie weszła w życie. Sala rozpraw była przepełniona. Przybyli na nią też naczelnicy sądów, sędziowie i adwokaci z Radymna, Jarosławia, Dobromila, Jaworowa, Mościsk, Niżankowic. Towarzystwo Prawnicze przemyskie może pochlubić się pierwsze w Polsce zainscenizowaniem takiej rozprawy próbnej”63.

Kiedy indziej władze Towarzystwa zorganizowały dla swoich członków wycieczkę do zakładu poprawczego w Przedzielnicy, by zapoznać ich z funkcjonowaniem tego typu placówki i formami pracy z młodzieżą, która weszła w kolizję z prawem ${ }^{64}$.

Od momentu reaktywowania w $1925 \mathrm{r}$. Towarzystwo systematycznie powiększało swoje zbiory biblioteczne, które pochodziły z zakupów z własnych środków pieniężnych i z darowizn członków. W 1932 r. biblioteka Towarzystwa liczyła oko-

60 Zob. więcej: Z. Andrzejewski, Adwokat dr Ludwik Grossfeld (1889-1955), „Palestra” 11-12/2006, s. 330-335.

61 Zob. „Tygodnik Przemyski”: rok 1927, nr 12, s. 3; rok 1928, nr 1, s. 3; nr 8, s. 4; nr 42, s. 2; rok 1935, nr 1, s. 3; nr 14, s. 14; rok 1938, nr 8, s. 4; nr 9, s. 4; nr 10, s. 4; nr 12, s. 4; nr 13, s. 4; nr 14, s. 4; $\mathrm{nr} 19$, s. 4; nr 40, s. 4; nr 41, s. 4; nr 42, s. 4; nr 43, s. 3; nr 44, s. 3; nr 48, s. 4; nr 49, s. 4; nr 50, s. 4; rok 1939, nr 3, s. 3; nr 4, s. 3; nr 5, s. 4; nr 6, s. 4; nr 8, s. 2; nr 9, s. 3; nr 11, s. 3; nr 12, s. 3; nr 16, s. 4; nr 18, s. 4; „Ziemia Przemyska”: rok 1926, nr 6, s. 3; rok 1927, nr 41, s. 3; nr 43, s. 3; rok 1928, nr 48, s. 6; rok 1929, nr 13, s. 7; nr 21, s. 5; rok 1930, nr 57, s. 5; rok 1931, nr 6, s. 4; rok 1932, nr 15, s. 4; nr 35, s. 3; rok 1938, nr 50, s. 5; „Nowy Głos Przemyski”: rok 1928, nr 10, s. 6; rok 1929, nr 18, s. 3; rok 1934, nr 11, s. 3; nr 43, s. 4; rok 1935, nr 40, s. 4; rok 1936, nr 42, s. 3; nr 43, s. 4; rok 1937, nr 41, s. 3; rok 1938, nr 11, s. 3; nr 17, s. 3; nr 18, s. 4; nr 46, s. 5; nr 47, s. 4. Tam też tematyka wykładów, referatów i odczytów.

62 Ibidem; „Ziemia Przemyska” 1929, nr 25, s. 7.

63 Ibidem, s. 7.

64 „Nowy Głos Przemyski” 1934, nr 43, s. 4. Brak dokumentacji Towarzystwa nie pozwala na poznanie innych form pracy stowarzyszenia. 
ło 600 woluminów z różnych gałęzi prawa, ekonomii politycznej oraz starodruków, a prenumerowano 16 czasopism ${ }^{65}$.

W okresie 1893-1939 prezesami Towarzystwa Prawniczego byli aktualni w owym czasie prezesi Sądu Okręgowego (Obwodowego), a to: dr Jan Dylewski (1893-1902), dr Antoni Wilecki (1914 i 1925-1929), dr Włodzimierz Hanińczak (1929-1932), dr Marian Podwiński (1932-1934) i dr Jan Prochazka (1934-1939) - wcześniej prokurator Sądu Okręgowego ${ }^{66}$. Funkcję wiceprezesa Towarzystwa w latach 1893-1914 pełnił adw. dr Leonard Tarnawski, a w latach 1925-1939 - adw. dr Leon Peiper, który nadawał ton pracom stowarzyszenia i wniósł znaczący wkład dla jego rozwoju.

W piątek, 25 listopada 1938 r., w sali zebrań Towarzystwa Prawniczego w starym budynku Sądu Okręgowego, odbyło się ostatnie posiedzenie członków Towarzystwa, na którym przemówienie pożegnalne wygłosił adwokat dr Józef Dobrzański ${ }^{67}$. Żegnając się z wiekowym gmachem Sądu Okręgowego, z którym szczególnie starsze pokolenie prawników związane było emocjonalnie i silnymi wspomnieniami, mecenas Dobrzański przypomniał historię i zmienne koleje losów tej siedziby przemyskiej Temidy. Mowę pożegnalną wygłosił też prezes Towarzystwa dr Jan Prochazka, który w budynku tego Sądu przeszedł wszystkie szczeble kariery prawniczej, od aplikanta po godność prezesa Sądu Okręgowego ${ }^{68}$.

Od 1 grudnia 1938 r. przemyskie Towarzystwo Prawnicze przeniosło swoje zebrania do nowo wybudowanej siedziby Sądu Okręgowego - gmachu przy ulicy Konarskiego 6. Działalność odczytową zainaugurował 2 grudnia wiceprezes Towarzystwa, dr Leon Peiper, referatem na temat: „Znaczenie przyznania w procesie karnym" ${ }^{69}$. Zgodnie z podtrzymaną tradycją, odczyty połączone z dyskusją odbywały się nadal w piątki o godzinie 18.00, w głównej sali rozpraw karnych nr 14 na II piętrze. Ostatni odczyt, na temat „Kanonicznego procesu małżeńskiego”, wygłosił 5 maja 1939 r. adwokat dr Adam Kropiński ${ }^{70}$. Z chwilą wybuchu II wojny światowej przemyskie Towarzystwo Prawnicze przestało istnieć i nigdy już się nie odrodziło.

Choć w swej historii przeżywało różne zawirowania i okresy swoistego impasu, to w ogólnym bilansie swojej działalności przemyskie Towarzystwo położyło ogromne zasługi na polu krzewienia i podnoszenia wiedzy wśród szerokich kręgów prawniczych, będąc prężnym ośrodkiem myśli prawnej ${ }^{71}$, a po roku 1932 stało się ostoją dla byłych członków zlikwidowanej w Przemyślu Izby Adwokatów.

Nie udało się zbadać losów biblioteki Towarzystwa, gdyż brak jest na ten temat przekazów źródłowych, tak ustnych, jak i pisemnych. Prawdopodobnie bogaty księgozbiór uległ rozproszeniu. Do dziś zachowały się jedynie pojedyncze egzemplarze, na które można się natknąć w bibliotekach Towarzystwa Przyjaciół Nauk i Archiwum Państwowego w Przemyślu. 0 tym, że były kiedyś własnością Towarzystwa Prawniczego, świadczą odciśnięte na nich pieczęcie.

65 „Ziemia Przemyska” 1932, nr 15, s. 4; „Głos Prawa” 1935, nr 3-4, s. 256.

66 „Przegląd Prawa i Administracji”, cz. I, Lwów 1893, s. 640; „Ziemia Przemyska”: rok 1925, nr 25, s. 4; rok 1929, nr 41, s. 5; rok 1932, nr 15, s. 4; nr 38, s. 4.

67 „Tygodnik Przemyski” 1938, nr 49, s. 3. Tam pełny tekst przemówienia.

68 Ibidem.

69 „Nowy Głos Przemyski” 1938, nr 4, s. 4 (zapowiedź).

70 „Tygodnik Przemyski” 1939, nr 18, s. 4.

71 T. Kotliński, Izba Adwokacka w Przemyślu, [w:] „V Międzynarodowe seminarium naukowe studentów i młodych pracowników nauki", Jarosław 2003, s. 75. 


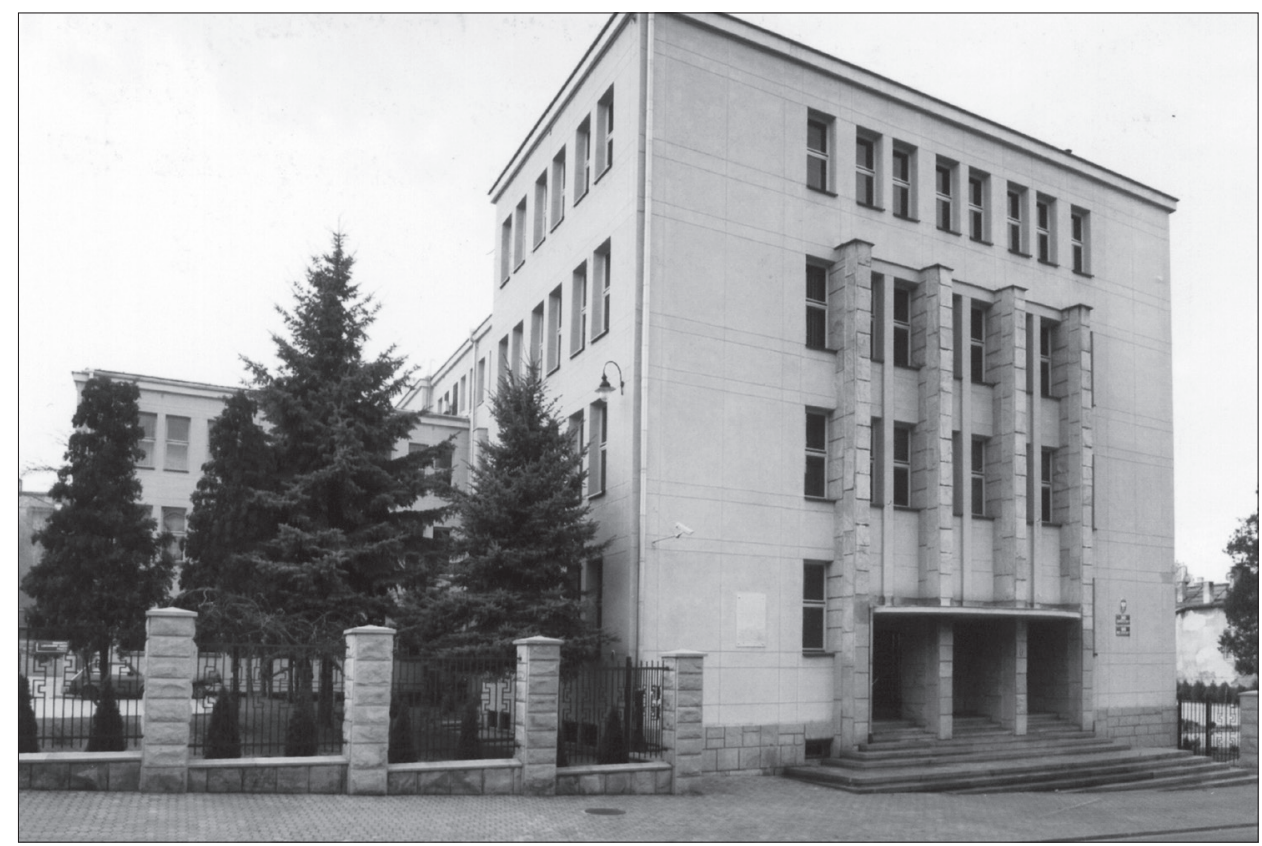

Fot. 1. Nowy gmach Sądu Okręgowego w Przemyślu przy ul. Konarskiego 6 (wygląd obecny) od 1 grudnia 1938 r. siedziba przemyskiego Towarzystwa Prawniczego.

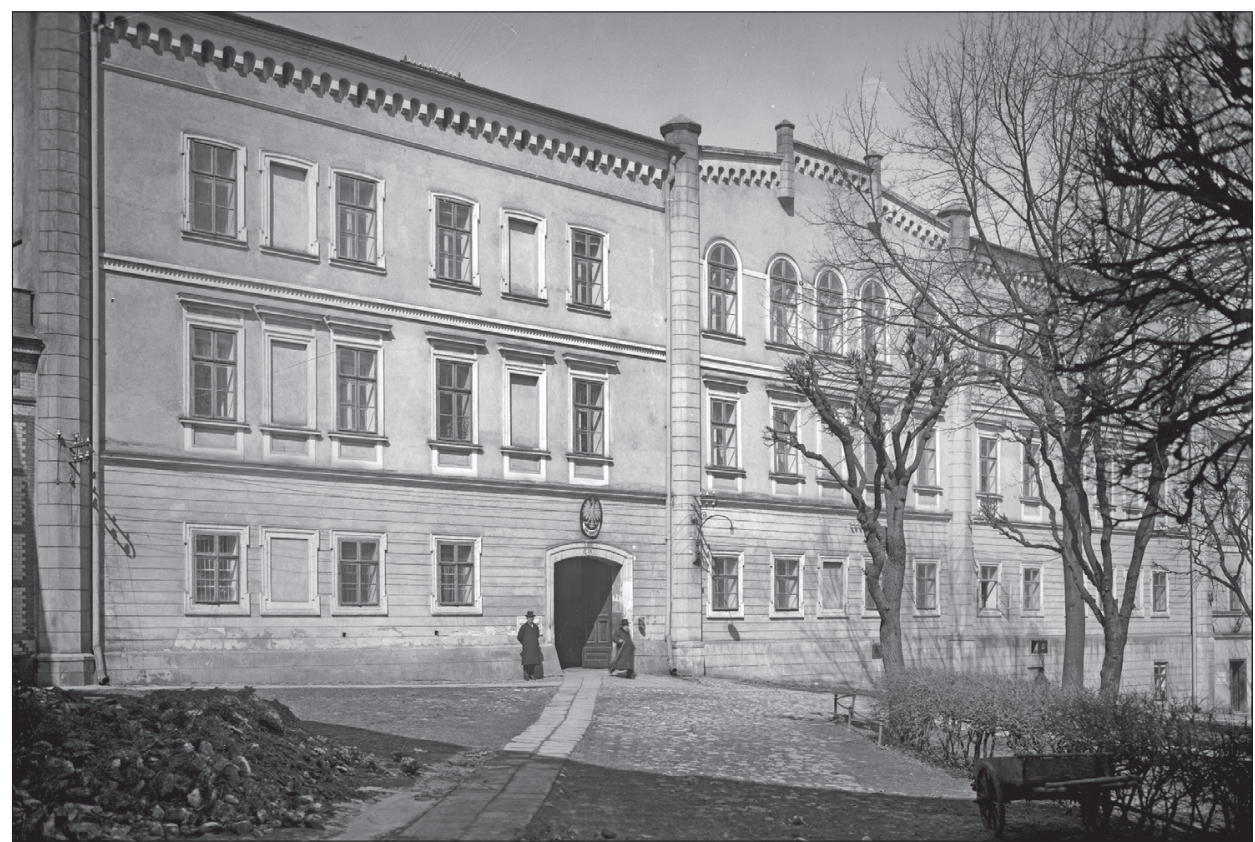

Fot. 2. Sąd Okręgowy (do 1914 r. Obwodowy) w Przemyślu, Rynek 26, gdzie odbywały się wykłady Towarzystwa Prawniczego do listopada 1938 r. 


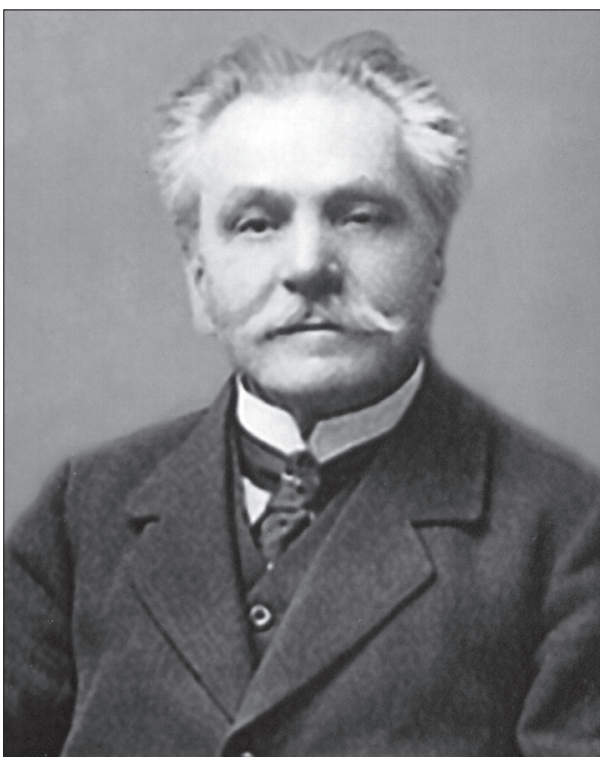

Fot. 3. Adwokat dr Leonard Tarnawski - wiceprezes przemyskiego Towarzystwa Prawniczego w latach 1893-1914.

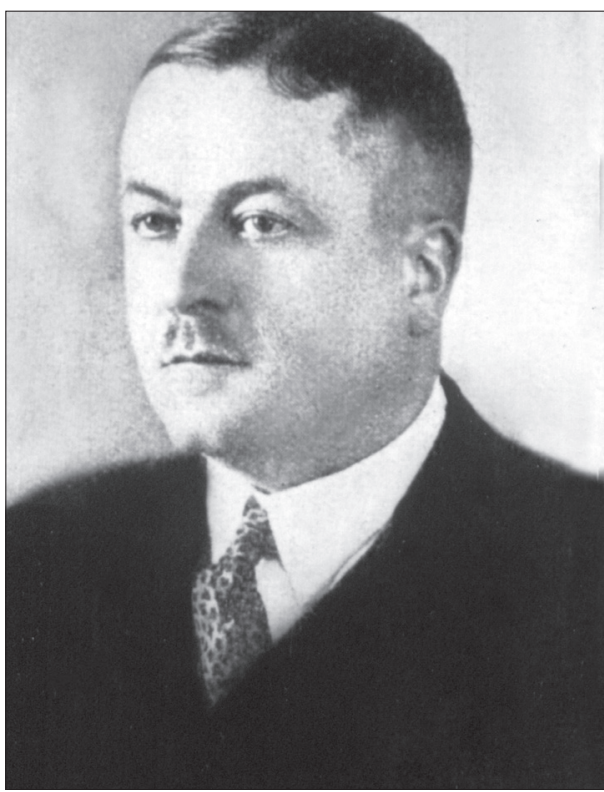

Fot. 5. Sędzia Sądu Okręgowego dr Marian Podwiński - prezes przemyskiego Towarzystwa Prawniczego w latach 1932-1934.

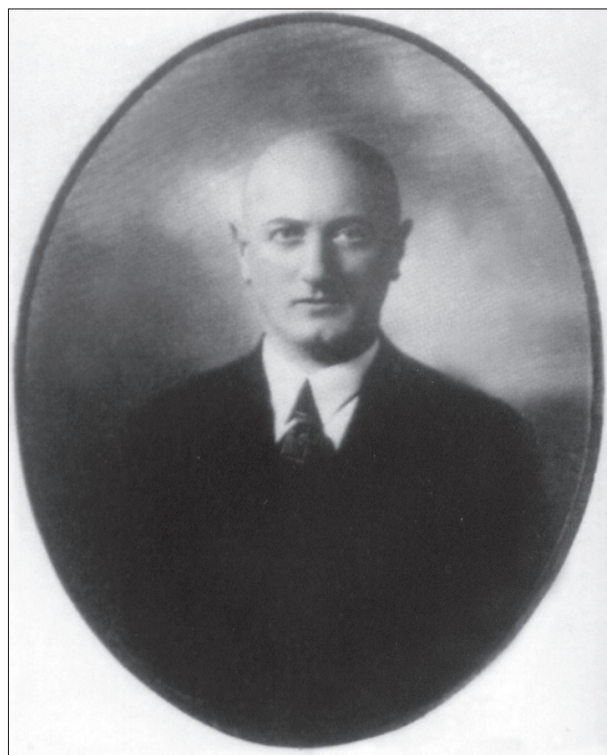

Fot. 4. Sędzia Sądu Okręgowego w Przemyślu dr Jan Prochazka - prezes Towarzystwa Prawniczego w latach 1934-1939.

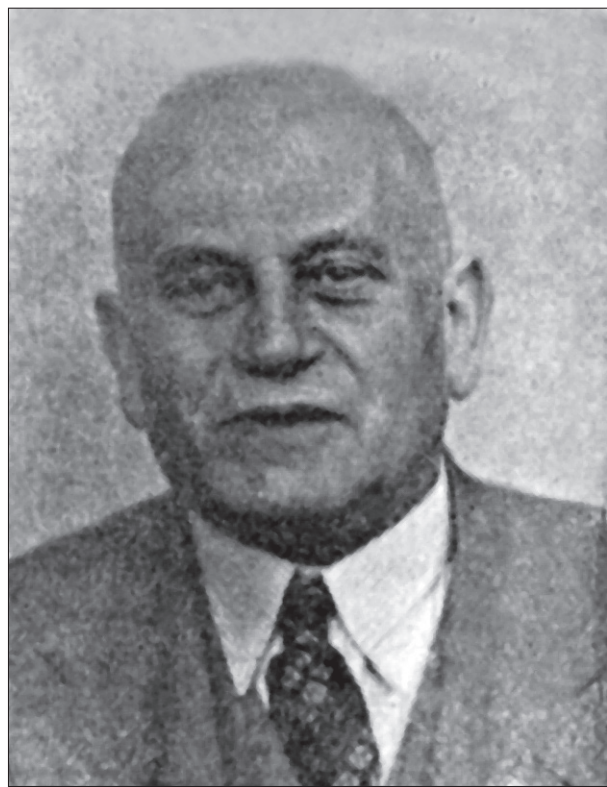

Fot. 6. Adwokat dr Leon Peiper - wiceprezes przemyskiego Towarzystwa Prawniczego w latach 1925-1939. 


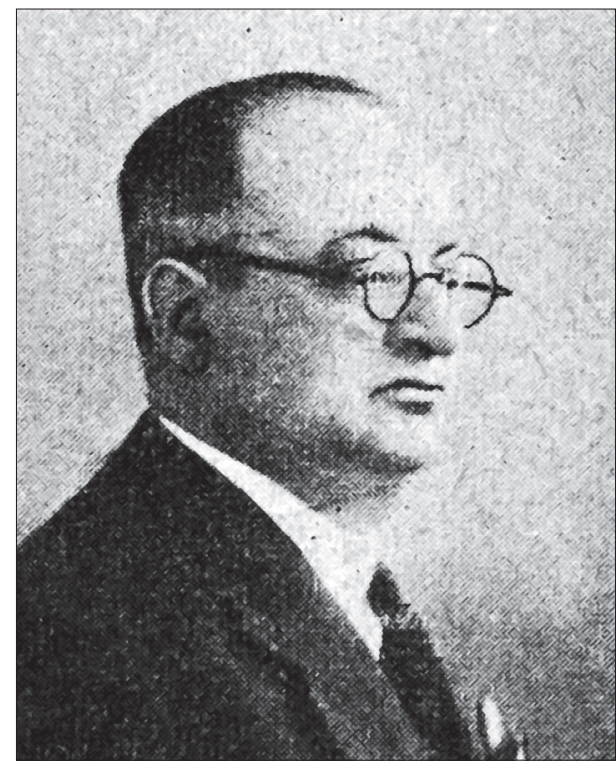

Fot. 7. Adwokat dr Maurycy Richter - członek Wydziału (Zarządu) Towarzystwa Prawniczego w Przemyślu w latach 1925-1932.

\section{Bibliografia}

\section{Czasopisma:}

„Echo Przemyskie” 1902.

"Gazeta Przemyska" 1889.

„Głos Prawa” 1927, 1935.

„Kuryer Przemyski” 1894, 1895, 1896.

„Nowy Głos Przemyski” 1928, 1929, 1934, 1935, 1936, 1937, 1938.

„Palestra” 2004, 2006, 2008, 2013.

„Prawnik” 1872, 1894.

„Przegląd Prawa i Administracji” 1893, 1894, 1895.

„Tygodnik Przemyski” 1927, 1928, 1935, 1938, 1939.

„Ziemia Przemyska” 1926, 1927, 1928, 1929, 1930, 1931, 1932, 1938.

\section{Źródła drukowane:}

Informator Rzeszowski Jarosławsko-Przemyski, Rocznik 1937/38, wyd. J. Brunelik, Lwów-Kraków 1937.

Kotliński T., Izba Adwokacka w Przemyślu, [w:] V Międzynarodowe Seminarium Naukowe Studentów i Młodych Pracowników Nauki, 24-25 listopada 2003, Wydawnictwo Naukowe Państwowej Wyższej Szkoły Zawodowej w Jarosławiu, Jarosław 2003. 
Leksykon Historii Polski, Wiedza Powszechna, Warszawa 1995.

Polskie Towarzystwo Ekonomiczne, Zeszyty Naukowe Polskiego Towarzystwa Ekonomicznego, nr 4, Kraków 2006.

Przemyskie Zapiski Historyczne, r. XVIII: 2010-2011, Przemyśl 2013.

Rocznik Przemyski, Historia, t. XLIV, z. 4, Towarzystwo Przyjaciół Nauk w Przemyślu, Przemyśl 2008.

Słownik Polskich Towarzystw Naukowych, t. II, cz. 3, Biblioteka PAN, Warszawa 2001. Sprawozdanie Wydziału Izby Adwokatów w Przemyślu za rok 1931, Przemyśl 1932. Szematyzm Królestwa Galicji i Lodomerii z Wielkim Księstwem Krakowskim na rok 1895, Lwów 1895.

\section{Abstract}

\section{The Historical Outline of Law Society in Przemysl (1872-1939) A Contribution to the History of Galician Law Societies}

The article presents the origin and activities of the Law Society in Przemysl, which was founded as the fourth in Galicia (after Cracow, Lviv and Kosovo) in 1872. However, the Society did not start its operation immediately. The initiative to establish a Law Society rekindled in 1889, but despite the favorable atmosphere and broad public support (e.g. from the local press), Przemysl had to wait for its LS until 1893. This time, the organization's activity was promising (the number of members was growing, public readings were being organized, a library began to be completed), but it suddenly collapsed in 1902, followed by a 12-year period of "lethargy". Activity resumed in 1914, but only for a few months, until the outbreak of World War I. Law Society was then reactivated in 1925, thanks to the joint efforts of the representatives of the local bar and court environment. The Society was once again very active (library, reading room, public readings on various branches of law, talks, regular general society meetings). The authorities of the organization also tried to promote unconventional forms of spreading legal knowledge, such as a mock trial or an excursion for the members to a correctional facility. In December 1938, the headquarters of the Society moved from the old building of the District Court (26 Rynek Street) to the newly constructed court building at 6 Konarskiego Street. With the outbreak of World War II, the Przemysl Law Society ceased to exist.

\section{Keywords:}

Przemysl, Galicia, Law Society, statutory activity, attorneys, judges. 